\title{
PUSAT PELATIHAN BAHASA UNIVERSITAS TANJUNGPURA
}

\author{
Janice Zaneta $^{1}$, Tri Wibowo Caesariadi ${ }^{2}$, Hamdil Khaliesh ${ }^{3}$ \\ ${ }^{1}$ Mahasiswa, Jurusan Arsitektur, Fakultas Teknik, Universitas Tanjungpura. \\ zanetajanice@gmail.com \\ ${ }^{2}$ Jurusan Arsitektur, Fakultas Teknik, Universitas Tanjungpura \\ ${ }^{3}$ Jurusan Arsitektur, Fakultas Teknik, Universitas Tanjungpura
}

Naskah diajukan pada: 14 Agustus 2021

Naskah revisi akhir diterima pada: 18 Agustus 2021

\begin{abstract}
Abstrak
Penguasaan berbahasa asing ialah keterampilan penting untuk bersaing di dunia Internasional ke depannya. UPT Bahasa Universitas Tanjungpura turut mendukung penguasaan berbahasa asing dan memiliki visi misi menjadi pusat pendidikan dan pelayanan bahasa internasional di Kalimantan Barat. Dengan berkembangnya Universitas Tanjungpura, saat ini Universitas Tanjungpura telah menyandang status BLU, sehingga fasilitas pendidikan perlu menyediakan area komersial untuk memenuhi status BLU ini. Oleh karena itu diperlukan Pusat Pelatihan Bahasa Universitas Tanjungpura yang dapat mendukung pembelajaran bahasa asing serta terdapat area komersial. Lokasi perancangan terletak di Jl. Daya Nasional, Bansir Laut, Kec. Pontianak Tenggara, Kota Pontianak, Kalimantan Barat, dengan luas $\pm 11.000 \mathrm{~m}^{2}$. Perancangan menggunakan metode perbandingan antara hasil observasi tapak, bangunan eksisting, studi literatur, dengan standar pusat pelatihan, serta menganalisis aspek internal dan eksternal tapak. Ide dasar tata ruang dalam dan luar perancangan yaitu mendukung pembelajaran bahasa asing dan menarik pengunjung untuk beraktivitas di Pusat Pelatihan Bahasa Universitas Tanjungpura. Hal tersebut diwujudkan dengan merancang ruang pendidikan yang memenuhi kriteria ruang pelatihan, ruang komersial yang memiliki nilai jual, dan zona publik yang bebas dikunjungi oleh masyarakat. Daya tarik ide bentuk bangunan perancangan merupakan segitiga yang menjadi ciri khas dari bentuk bangunan Universitas Tanjungpura. Bangunan diselimuti secondary skin dengan motif pola khas Universitas Tanjungpura.
\end{abstract}

Kata-kata Kunci: Pelatihan, Pusat Bahasa, Universitas Tanjungpura

\begin{abstract}
Mastery of foreign languages is an important skill to compete in the international world in the future. The Language Unit of Universitas Tanjungpura also supports the mastery of foreign languages and has a vision and mission to become a center for international language education and services in West Kalimantan. With the development of Universitas Tanjungpura, Universitas Tanjungpura currently has BLU status, so educational facilities need to provide commercial areas to fulfill this BLU status. Therefore, a Universitas Tanjungpura Language Training Center is needed that can support foreign language learning and there is a commercial area. The design location is located on Daya National Street, Sea Bansir, Southeast Pontianak Subdistrict, Pontianak City, West Kalimantan, with an area of $\pm 11,000$ $\mathrm{m}^{2}$. The design uses a comparison method between the results of site observations, existing buildings, literature studies, with training center standards, as well as analyzing internal and external aspects of the site. The basic idea of interior and exterior spatial planning is to support foreign language learning and attract visitors to have activities at the Universitas Tanjungpura Language Training Center. This is realized by designing an educational space that meets the criteria for a training room, a commercial space that has a selling value, and a public zone that is free to be visited by the public. The appeal of the idea of a design building is a triangle which is the hallmark of the Universitas Tanjungpura building form. The building is covered with secondary skin with a typical pattern of the Universitas Tanjungpura.
\end{abstract}

Keywords: Training, Language Centre, Universitas Tanjungpura 


\section{Pendahuluan}

Bahasa ialah sarana komunikasi yang digunakan sekumpulan manusia di suatu kelompok dan daerah tertentu. Pada era ini, banyak orang sudah mengetahui pentingnya penguasaan bahasa yang tidak hanya bahasa lokal tetapi juga bahasa asing. Hal ini dikarenakan kemampuan berbahasa asing dibutuhkan untuk bersaing di zaman globalisasi dan pasar internasional.

Universitas Tanjungpura turut serta dalam mendukung penyelenggaraan pembelajaran bahasa asing agar mahasiswa-mahasiswi Indonesia dapat menguasai bahasa asing khususnya yang berkuliah di Universitas Tanjungpura. Universitas Tanjungpura (UNTAN) mempunyai Unit Pelaksana Teknis (UPT) yaitu suatu unit pendukung dalam kawasan Universitas Tanjungpura. UPT Bahasa UNTAN menyediakan layanan berupa pengajaran dan pelatihan bahasa asing untuk mahasiswa/i UNTAN maupun masyarakat umum. Visi UPT Bahasa UNTAN yaitu menjadi pusat pendidikan dan pelayanan bahasa internasional di Kalimantan Barat yang menghasilkan manusia yang handal dalam menguasai bahasa tersebut untuk berkompetisi di tingkat nasional dan internasional.

Keadaan eksisting UPT Bahasa UNTAN secara keseluruhan mempunyai beberapa kekurangan. Hal tersebut terdiri dari kebutuhan ruang yang belum terpenuhi, fasilitas ruang yang belum memadai, bangunan-bangunan yang tidak memiliki satu kesatuan, dan lingkungan belajar yang kurang mendukung. Hal-hal tersebut mempengaruhi minat belajar bahasa asing pelajar, padahal supaya memenuhi persyaratan pada bidang pengasahan bahasa asing diperlukan tempat pembelajaran bahasa asing yang memadai.

Berdasarkan berita Kampus UNTAN tanggal 20 November 2017, berlandaskan pada Keputusan Menteri Keuangan Republik Indonesia no 830/KMK.05/2017 tanggal 13 November 2017, Universitas Tanjungpura resmi menerapkan pola pengelolaan keuangan badan layanan umum (BLU). Hal ini berarti seluruh penerimaan non pajak dikelola secara otonomi oleh universitas negeri sendiri, sehingga universitas perlu memaksimalkan fasilitas yang ada untuk mendapatkan pemasukan. UPT Bahasa di bawah naungan Universitas Tanjungpura juga berstatus BLU sehingga perlu memaksimalkan fasilitas yang ada sehingga memiliki nilai jual. Hal ini menyimpulkan bahwa UPT Bahasa UNTAN tidak lagi sekadar bangunan pendidikan, tetapi juga bangunan yang bersifat komersial.

Berdasarkan pernyataan di atas, dapat disimpulkan banyak kalangan yang ingin mempelajari bahasa asing namun belum ada tempat pembelajaran bahasa asing yang mendukung minat dan motivasi pelajar tersebut. UPT Bahasa UNTAN masih memiliki kekurangan-kekurangan untuk memenuhi kebutuhan ruang mahasiswa/I dan kalangan umum yang mau mempelajari bahasa asing. UPT Bahasa UNTAN juga berstatus BLU yang harus memaksimalkan fasilitas yang ada sehingga memiliki nilai jual. Oleh karena itu, penulis berinisiatif untuk mendesain Pusat Pelatihan Bahasa yang dapat mewadahi dan menunjang kegiatan pembelajaran bahasa asing, serta bersifat komersial di Universitas Tanjungpura.

\section{Kajian Pustaka}

Berdasarkan pendapat Hamalik (2007) pelatihan adalah serangkaian upaya yang dilakukan secara berkesinambungan, bertahap, dan mengarah kepada suatu tujuan tertentu. Sedangkan bagi Rivai dan Sagala (2011) pelatihan adalah proses belajar untuk meningkatkan keterampilan yang dilakukan dalam waktu yang relatif singkat dengan lebih mengutamakan pada pembelajaran praktik daripada teori.

Merujuk Peraturan Pemerintah Nomor 23 Tahun 2005 yang diperbaharui Peraturan Pemerintah Nomor 74 Tahun 2012, pada pasal 1 disebutkan bahwa "Badan Layanan Umum (BLU) adalah instansi di lingkungan Pemerintah yang dibentuk untuk memberikan pelayanan kepada masyarakat berupa penyediaan barang dan/atau jasa yang dijual tanpa mengutamakan mencari keuntungan dan dalam melakukan kegiatannya didasarkan pada prinsip efisiensi dan produktivitas." 
Berdasarkan Anita Lie yang dikutip dari Suherman (2011) menuturkan bahwa dalam pengajaran bahasa, biasanya ada empat bidang keterampilan yang dijadikan acuan kurikulum: mendengarkan, membaca, berbicara, dan menulis.

Secara sederhana Noe (2002) mengemukakan tiga hal yang harus diperhatikan dalam menentukan tempat pelatihan yaitu: Comfortable and accessable (nyaman secara fisik maupun psikologis dan secara geografis mudah dijangkau); Quite, private, and free from interruptions (tenang, terjaga dari berbagai gangguan, baik suara, udara, maupun lainnya); dan Sufficient space for trainees to move easily around in, offers enough room for trainees to see each other, the trainer, and any visual displays or examples that will be used in training video, product samples, charts, slides. (memiliki ruang yang memudahkan peserta pelatihan untuk bergerak, melihat peserta lain dan tayangan yang ditampilkan dalam pelatihan). Hal ini berkaitan dengan Laird dalam Sugiyono (2002) yang mengungkapkan 4 kriteria sebuah ruangan pelatihan, antara lain fleksibilitas, kedap suara, pencahayaan yang baik, dan ventilasi.

\section{Metode}

Metode perancangan merupakan sebuah proses perancangan meliputi pencarian data dan teknik pengumpulan data, teknik analisis, hingga tahap perancangan. Perancangan Pusat Pelatihan Bahasa ini menggunakan metode perancangan R.Whitaker yang memiliki tujuh tahapan (Snyder \& Catanese, 1989). Pertama merupakan tahap pengenalan dengan mencari topik-topik bersangkutan sehingga menjadi dasar perancangan Pusat Pelatihan Bahasa Universitas Tanjungpura. Kedua adalah tahap definisi yang mendefinisikan permasalahan secara makro, tujuan, sasaran, dan manfaat serta lingkup perencanaan dan perancangan dari wawancara, studi kasus, dan informasi bidang kebahasaan. Ketiga yaitu tahap persiapan yaitu pengumpulan data primer yang berasal dari pengamatan tapak eksisting, wawancara dengan pihak terkait, serta pengumpulan data sekunder dari studi kasus dan literatur. Keempat yaitu tahap analisis yang dimaksudkan untuk mendapatkan solusi permasalahan yang terdiri dari analisis fungsi, pelaku, ruang, lokasi, tapak, bentuk, struktur, utilitas, dan fisika bangunan. Kelima yaitu tahap sintesis yaitu suatu gambaran konsep rancangan yang digambarkan melalui skematik ruang luar, skematik ruang dalam, dan bentuk tiga dimensi yang menguraikan penerapan analisis perancangan. Keenam adalah tahap evaluasi yang menyusun semua konsep perencanaan dan perancangan.Terakhir adalah tahap re-evaluasi yaitu tahap pengecekan semua hasil akhir berupa gambar pra-rancangan, gambar rencana arsitektural, gambar rencana struktural, dan gambar rencana utilitas.

\section{Hasil dan Pembahasan}

Lokasi tapak Pusat Pelatihan Bahasa Universitas Tanjungpura berada di Jalan Daya Nasional, Bansir Laut, Kec. Pontianak Tenggara, Kota Pontianak, Kalimantan Barat. Berlandaskan Perda No 2 Tahun 2013 tentang RTRW Kota Pontianak tahun 2013- 2033 dan Dinas Cipta Karya Tata Ruang terkait peraturan lingkungan yaitu, peruntukan kawasan pendidikan, KDB $60 \%$, KLB 4, KDH 40 $\%$, dan GSB 8 meter simetris. 

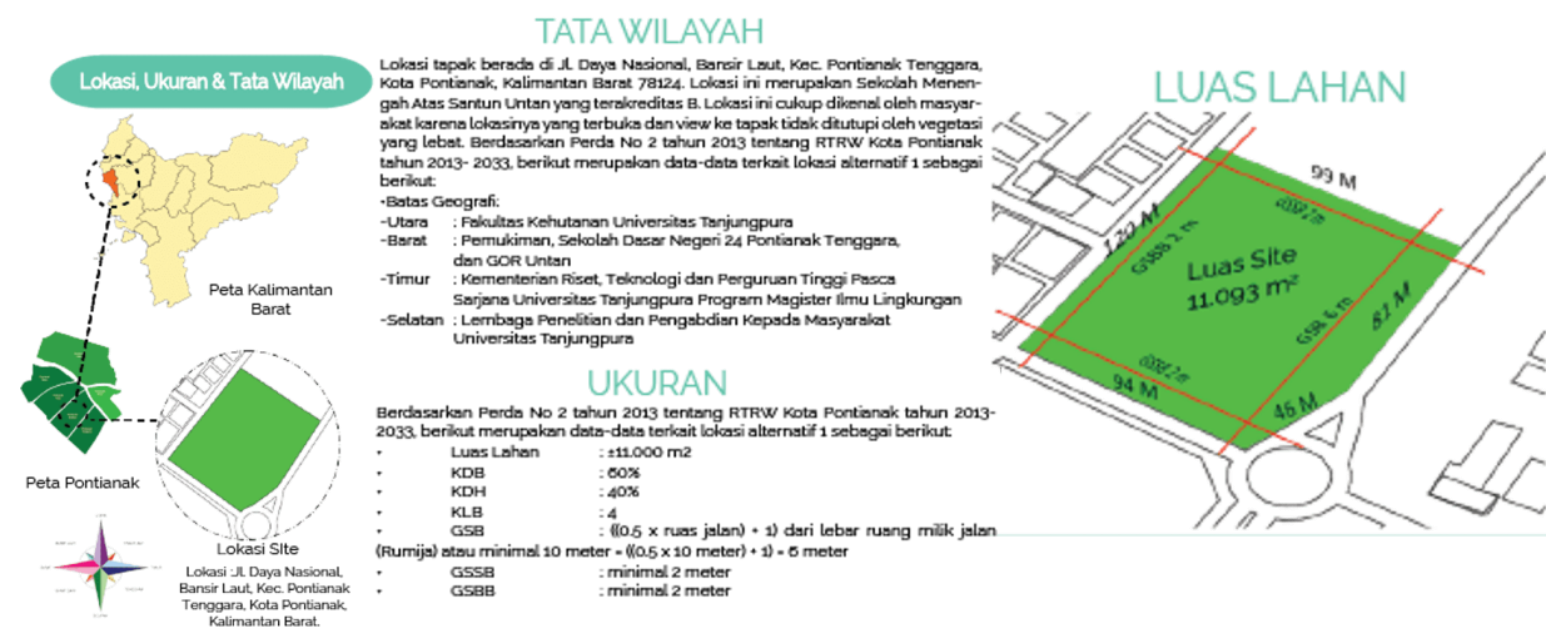

Gambar 1. Lokasi Perancangan Pusat Pelatihan Bahasa Universitas Tanjungpura Sumber: Penulis, 2021

\section{Landasan Konseptual}

Hasil dari landasan konseptual ialah konsep perencanaan dan perancangan Pusat Pelatihan Bahasa Universitas Tanjungpura. Tahap pertama analisis diperuntukkan untuk mengenali permasalahan sehingga mendapatkan solusi. Fungsi perancangan didapatkan berlandaskan teori dan observasi terkait aktivitas dan kegiatan di dalam pusat pelatihan bahasa. Fungsi terdiri dari tiga kelompok yang terdiri dari dua fungsi, yaitu kelompok fungsi utama, kelompok fungsi penunjang, dan kelompok fungsi pendukung. Kelompok fungsi utama yaitu, fungsi pendidikan untuk mendukung pembelajaran bahasa asing. Kelompok fungsi penunjang yaitu fungsi komersial dengan merancang ruang yang memiliki nilai jual dan fungsi rekreasi untuk bersantai dan refreshing. Kelompok fungsi pendukung ialah fungsi pengelolaan dan servis yang memerlukan kantor pengelola dan ruang servis. Berdasarkan data survey analisis penulis, pelaku-pelaku Pusat Pelatihan Bahasa Universitas Tanjungpura dapat dikelompokkan menjadi tiga berdasarkan tiga fungsi perancangan: Fungsi utama yaitu kelompok pelajar dan pengajar, Fungsi penunjang yaitu kelompok pengunjung dan pengelola komersial, Fungsi pendukung yaitu kelompok pengelola UPT dan pengelola servis.
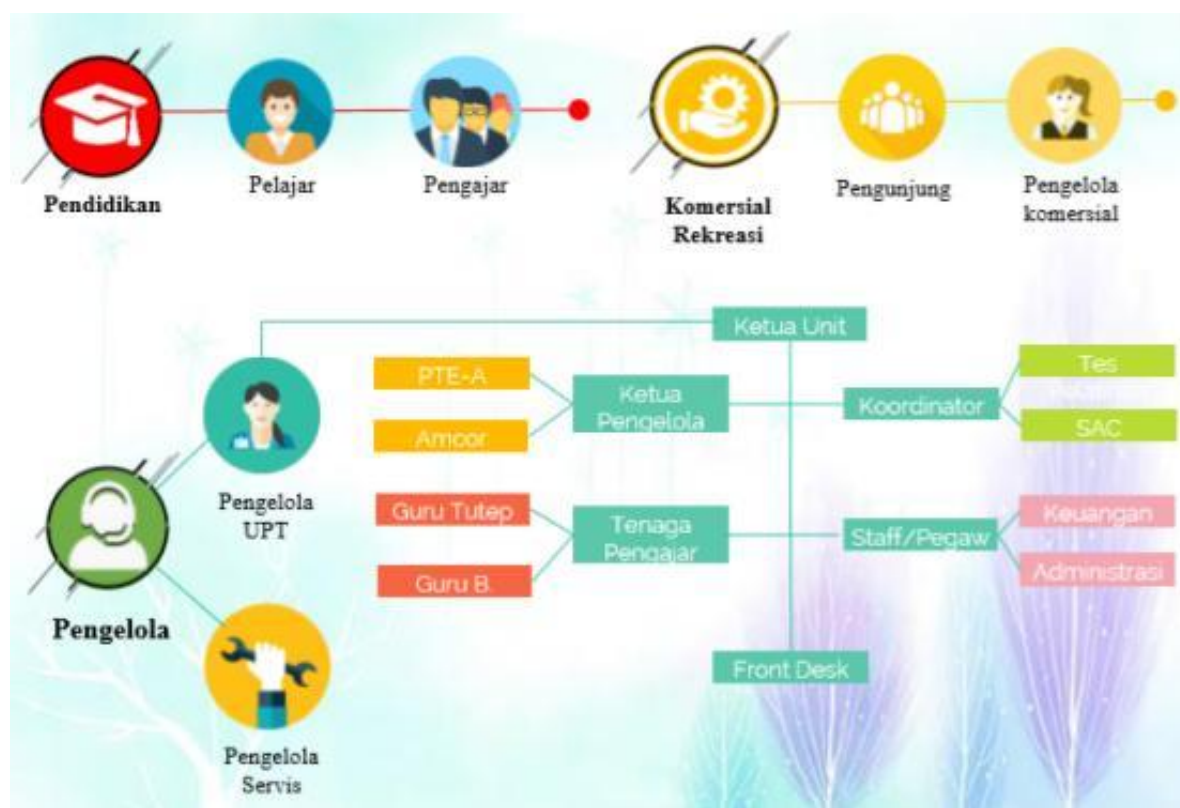

Gambar 2. Fungsi dan Pelaku Pusat Pelatihan Bahasa Universitas Tanjungpura

Sumber: Penulis, 2021 
Kebutuhan ruang Pusat Pelatihan Bahasa Universitas Tanjungpura berjumlah 43 ruang. Fungsi pendidikan merupakan zona publik dan semi-privat yaitu lobby, ruang resepsionis, ruang informasi, ruang kelas, dan plaza corner. Fungsi komersial dan rekreasi merupakan zona publik dan zona servis yaitu cafetaria, dapur, dan ruang penyimpanan makanan. Fungsi fasilitas umum merupakan zona publik, semi-publik, dan servis yaitu perpustakaan, ruang loker, ruang diskusi, ruang aula serbaguna, ruang amphiteather, ruang backstage, ruang persiapan, mushola, ruang wudhu, dan lavatory. Fungsi pengelola UPT merupakan zona privat yaitu lobby pengelola, ruang tamu, ruang absen, ruang rapat, ruang arsip, ruang ketua unit, ruang ketua pengelola PTE-A, ruang ketua pengelola Amcor, ruang koordinator tes pelatihan, ruang koordinator SAC, ruang pengajar, ruang staff keuangan, dan ruang administrasi. Fungsi pengelola servis merupakan zona servis yaitu ruang pompa, ruang genset, ruang panel listrik, ruang PABX, ruang CCTV, ruang sound system, ruang janitor, dan ruang pengangkutan sampah.

Kesimpulan total dari keseluruhan luas kebutuhan ruang adalah 3.858,586 $\mathrm{m}^{2}$ tanpa RTNH (parkir) $2.088 \mathrm{~m}^{2}$ dan RTH 4.637,404 $\mathrm{m}^{2}$, RTH 10\% dari keseluruhan 1.058,399 $\mathrm{m}^{2}$. Jadi besaran minimal Pusat Pelatihan Bahasa Universitas Tanjungpura adalah $11.642,389 \mathrm{~m}^{2}$.

Analisis tapak Pusat Pelatihan Bahasa Universitas Tanjungpura terdiri dari perletakan, orientasi, sirkulasi, zonasi, dan vegetasi. Massa bangunan diletakkan pada tengah tapak sedikit ke timur laut yang dimaksudkan untuk menjauhkan bangunan dari sumber kebisingan tertinggi yaitu Jalan Daya Nasional dan Jalan Karangan.

Kedua, untuk memanfaatkan view ke tapak dari berbagai sisi tapak. Ketiga, untuk menaati peraturan tata wilayah yaitu GSB (garis sempadan bangunan) dan GSSB (garis sempadan samping bangunan). Keempat, meletakkan taman dan plaza di depan tapak karena dekat dengan pedestrian eksisting di sisi Jalan Daya Nasional.

Orientasi utama menghadap tenggara dan selatan. Analisis orientasi bangunan menghadap ke tenggara agar pusat pelatihan bahasa gampang terlihat dari Jalan Daya Nasional yang merupakan jalan utama. Sedangkan untuk orientasi ke arah selatan agar mendapatkan view terbaik pada tapak yaitu view tugu UNTAN. Orientasi ke tenggara dan selatan juga dimaksudkan untuk meminimalisir bidang bangunan yang menghadap langsung ke arah timur dan barat.

Analisis sirkulasi pengelola diletakkan pada timur laut yang dapat difungsikan juga sebagai sirkulasi servis yang masuk dari Jalan Nanga Pinoh. Sirkulasi pengunjung umum terdapat dua jalur, jalur utama dari Jalan Daya Nasional dan jalur kedua dari Jalan Karangan. Sirkulasi pedestrian diletakkan pada bagian selatan tapak yaitu taman dan plaza yang mengarah ke bundaran tugu UNTAN. Sirkulasi keluar kendaraan terletak berbagai sisi tapak yaitu Jalan Daya Nasional, Jalan Karangan, dan Jalan Nanga Pinoh. Hal ini dimaksudkan agar tidak terjadi kemacetan kendaraan.

Analisis zonasi menempatkan zona publik pada area selatan, tenggara, dan barat daya tapak yang dekat dengan sisi Jalan Daya Nasional dan Jalan Karangan yang ramai dilewati masyarakat. Zona semi publik diletakkan dekat area parkiran umum di bagian tengah tapak. Zona publik sebagai tempat rekreasi diletakkan pada area selatan dan tenggara untuk mendukung kegiatan publik masyarakat. Fungsi komersial zona publik pada area tenggara untuk memperoleh view terbaik. Zona semi-privat berada pada tengah tapak sehingga mudah dijangkau oleh pelajar dari parkiran umum. Zona privat terletak pada area dengan tingkat kebisingan rendah yaitu di bagian utara dan timur laut. Zona servis terletak di barat laut dan barat yang tempatnya tersembunyi dan condong di tengah sehingga mudah dijangkau dari seluruh sisi bangunan. Parkiran berada di area barat, tenggara, dan timur laut guna memberdayakan area GSB dan GSSB.

Vegetasi peneduh diletakkan pada sisi yang terkena langsung dengan matahari pagi dan sore. Vegetasi buffer diletakkan pada sepanjang Jalan Daya Nasional, Jalan Karangan, dan Jalan Nanga Pinoh. Vegetasi pengarah diletakkan pada sisi akses masuk kendaraan. Vegetasi estetis diletakkan pada area plaza dan taman. 


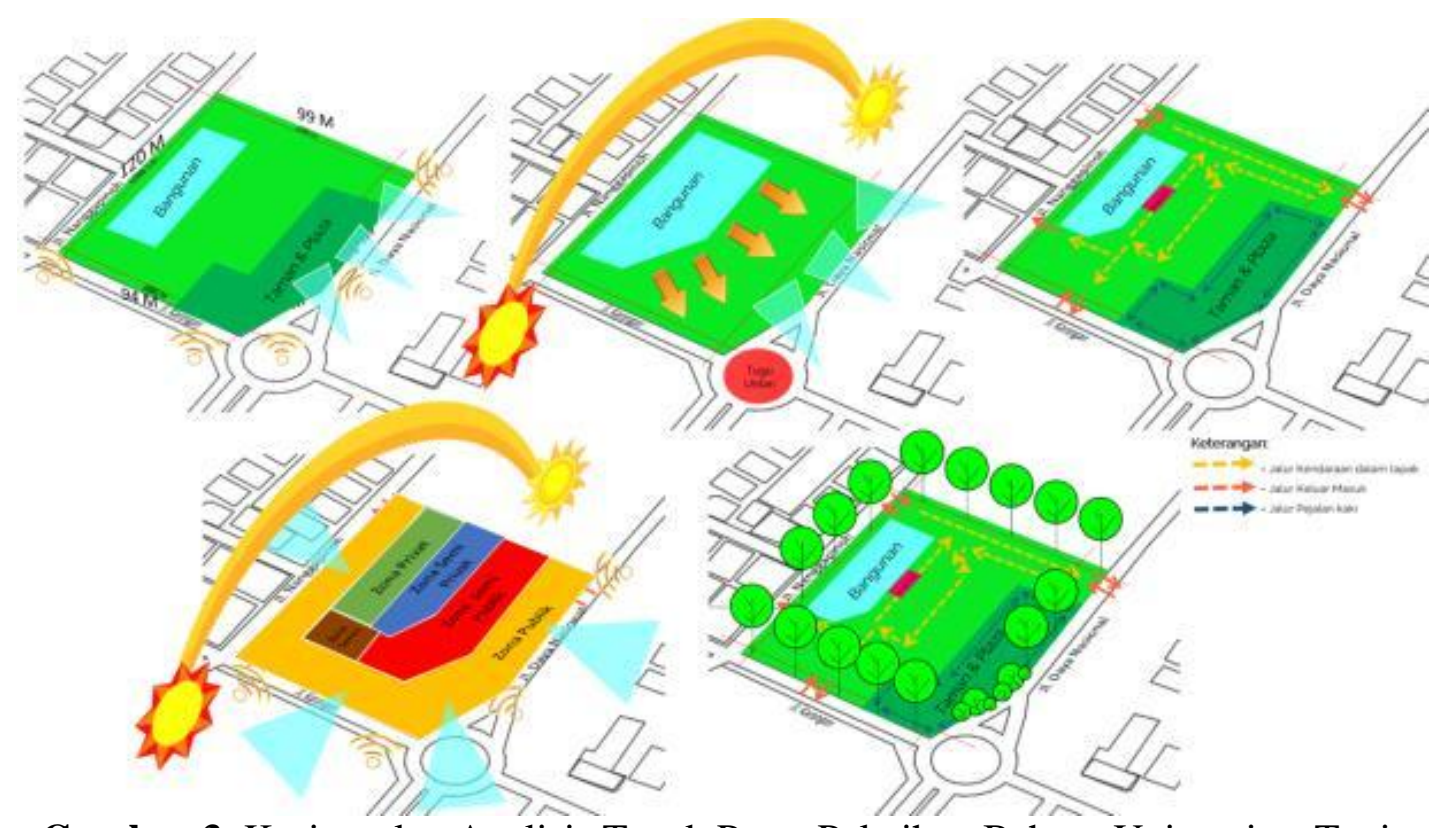

Gambar 3. Kesimpulan Analisis Tapak Pusat Pelatihan Bahasa Universitas Tanjungpura Sumber: Penulis, 2021

Gubahan massa Pusat Pelatihan Bahasa Universitas Tanjungpura menerapkan analisis internal dan eksternal. Pusat Pelatihan Bahasa Universitas Tanjungpura adalah unit pendidikan yang berfokus pada keefektifan dan fungsional. Filosofis karakter bahasa yang dinamis dan bervariasi menjadi pertimbangan untuk merancang ruang yang memberikan kebebasan pada pengguna ruang tersebut. Selain pertimbangan pada tata ruang dalam, juga diperhatikan tata ruang luar sehingga penggunaan tapak dapat digunakan secara efektif dan mendukung kegiatan di luar bangunan.

\section{Analisis Gubahan Bentuk}

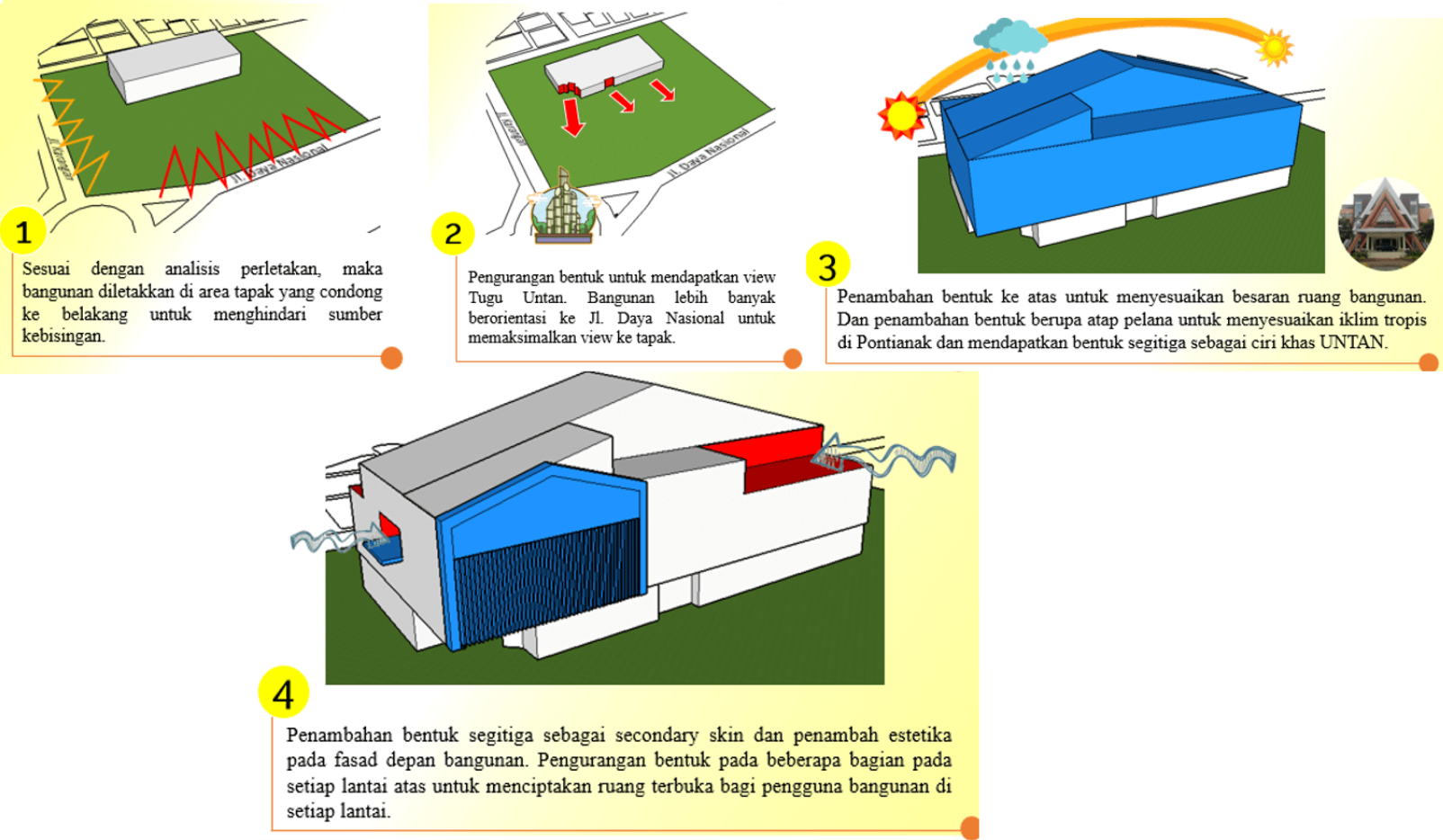

Gambar 4. Gubahan Massa Pusat Pelatihan Bahasa Universitas Tanjungpura Sumber: Penulis, 2021 
Konsep gubahan bentuk Pusat Pelatihan Bahasa Universitas Tanjungpura menerapkan ide bentukan dasar yang diambil dari analisis tapak yang menyesuaikan potensi tapak. Bangunan terdiri dari satu massa yang memiliki fungsi pendidikan, komersial \& rekreasi, fasilitas umum, dan pengelola. Pemilihan atap dak pada bangunan untuk memudahkan peletakan alat-alat servis seperti mesin outdoor VRV dan roof tank. Pemilihan atap pelana untuk menyesuaikan iklim tropis Pontianak. Pemilihan atap kaca untuk memaksimalkan pencahayaan alami pada bangunan.

Pusat Pelatihan Bahasa Universitas Tanjungpura merupakan bangunan satu massa dengan empat lantai. Grid struktur bangunan terdiri dari beberapa modulasi, yaitu 9 × 6 m, 6 × 6 m, dan 6 × 3 meter. Sistem struktur bawah menggunakan pondasi titik dengan penguatan dari mini pile. Jenis mini pile pada perancangan ini adalah mini pile dengan ukuran diameter 0,40 m sedalam kurang lebih 20 meter bermaterial beton bertulang.

Sistem struktur atas bangunan menggunakan sistem rangka beton bertulang. Berdasarkan perhitungan struktur, untuk bentangan $6 \times 6 \mathrm{~m}$ dan $6 \times 3 \mathrm{~m}$ menggunakan ukuran balok induk yaitu 0,25 × 0,50 m menggunakan ukuran balok anak $0,20 \times 0,40 \mathrm{~m}$, sedangkan untuk bentangan $9 \times 6 \mathrm{~m}$ menggunakan ukuran balok induk yaitu $0,40 \times 0,75 \mathrm{~m}$ dan lebar kolom bundar berdiamater 0,50 m. Pertimbangan dari penggunaan penutup atap bitumen yaitu kemampuannya dalam meredam kebisingan, tahan air, tahan pada cuaca kemarau dan hujan, berat material yang ringan, memiliki nilai estetika, dan hanya memerlukan rangka kuda-kuda dan gording dalam pemasangannya. Untuk atap bentangan menggunakan penutup atap dak beton dengan plat lantai bondek dikarenakan untuk menghemat penulangan dan memudahkan peletakan alat-alat servis di atas bangunan.

\section{Konsep Gubahan Bentuk}

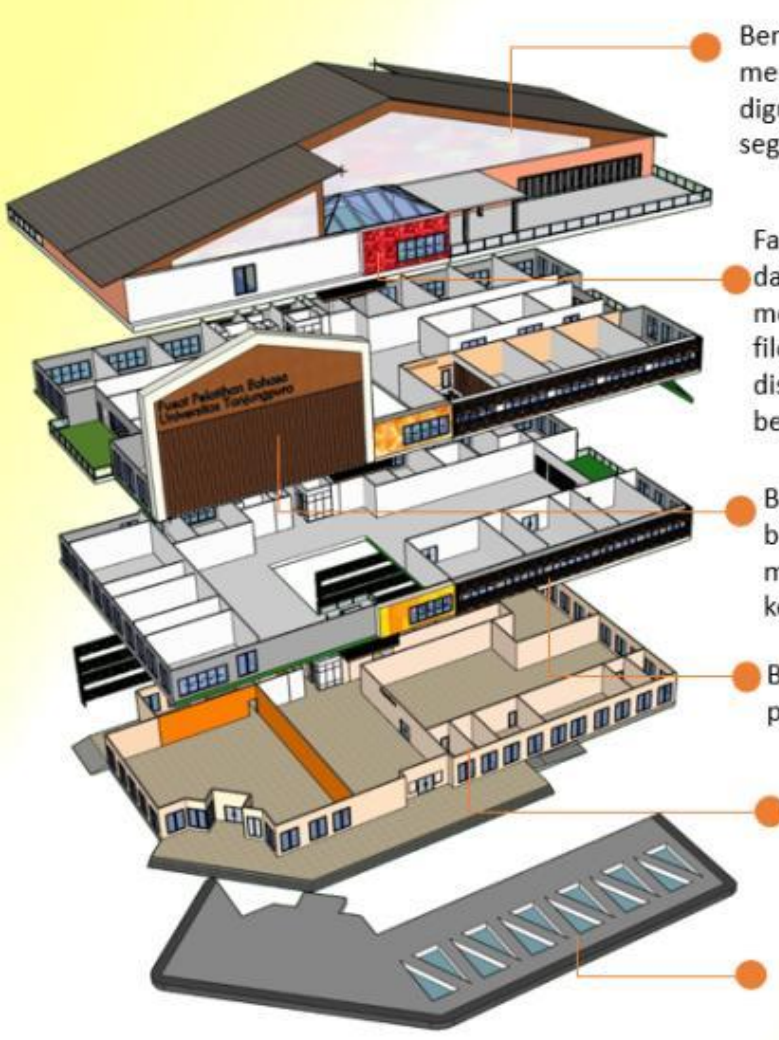

Bentukan atap menyesuaikan iklim tropis Pontianak yang memiliki curah hujan yang tinggi sehingga atap yang digunakan memiliki kemiringan $15^{\circ}$ dan mendapat bentuk segitiga yang menjadi ciri khas dari bangunan UNTAN.

Fasad pada bagian depan menggunakan warna merah, jingga, dan kuning untuk menciptakan kontras warna untuk menimbulkan kesan menarik. Ketiga warna ini diambil dari filosofi bahasa yang bervariasi namun begitu indah jika disatukan, seperti warna merah, jingga, dan kuning yang bervariasi, ceria, dan indah jika dipadukan.

Bentukan fasad berbentuk segitiga menyesuaikan konsep bentuk segitiga pada bangunan dengan kisi-kisi kayu yang mencirikan ciri khas Kalimantan Barat yang kaya dengan kekayaan hutan alamnya.

Bentukan secondary skin mengikuti pola motif yang digunakan pada bangunan UNTAN eksisting.

Fasad menggunakan warna dasar netral yaitu warna putih, abu-abu, coklat, dan cream untuk menimbulkan perasaan nyaman, natural, dan stabil secara psikologis.

Kanopi drop off menyesuaikan bentuk miring pada lantai 1 dengan bentukan kaca berbentuk segitiga untuk memanfaatkan pencahayaan alami.

Gambar 5. Konsep Gubahan Bentuk Pusat Pelatihan Bahasa Universitas Tanjungpura Sumber: Penulis, 2021 
Konsep utilitas Pusat Pelatihan Bahasa Universitas Tanjungpura meliputi sistem jaringan air, jaringan listrik, jaringan tata udara, keamanan bangunan dan persampahan. Sistem down feed digunakan pada sistem jaringan air karena kelebihannya yang hemat listrik dan membuat pompa air menjadi lebih awet. Ground water tank (GWT) disediakan untuk kebutuhan air bersih pengunjung dan pengelola bangunan yang akan dipompa dan didistribusikan oleh roof water tank (RWT), serta penanggulangan kebakaran darurat. Sistem jaringan air kotor memiliki alur yaitu dari sumber saniter ke bak kontrol kemudian ke septictank. Kotoran ditampung di septictank diarahkan ke riol kota.

Sistem jaringan listrik terkait pencahayaan menerapkan penerangan lampu LED. Sistem jaringan CCTV indoor maupun outdoor menggunakan CCTV yang beradius $360^{\circ}$. Sistem jaringan komunikasi terkait instalasi telepon berasal dari jaringan Telkom yang disalurkan ke PABX dan unit extention phone. Sistem jaringan internet menerapkan jaringan wifi menggunakan router. Sistem jaringan tata suara menggunakan listrik dari PLN atau genset yang disalurkan ke speaker selector. Sistem jaringan tata udara menerapkan sistem AC variable refrigerant volume (VRV) yang memiliki banyak kelebihan.

Sistem keamanan bangunan terkait penangkal petir menerapkan sistem Thomas. Penangkal petir yang digunakan adalah sistem Thomas tipe 25 yang dapat menjangkau pada radius 25 meter. Sistem keamanan kebakaran menggunakan detektor asap yang terpasang setiap jarak 10 meter, alat pemadam api ringan (APAR) yang terpasang setiap 10 meter, hidran yang terpasang setiap jarak 40 meter, sprinkler yang memiliki semburan beradius $20 \mathrm{~m}^{2}$ dan terpasang setiap jarak 5 meter, perletakkan tangga darurat dengan radius jangkauan 30 meter, serta hidran halaman dengan jangkauan 20 meter yang terpasang setiap jarak 60 meter.

Sistem persampahan di dalam bangunan dilakukan dengan mengumpulkan sampah di ruang penampungan sampah menggunakan kereta dorong yang nantinya akan diangkut oleh truk kebersihan kota.

\section{Konsep Utilitas Bangunan}

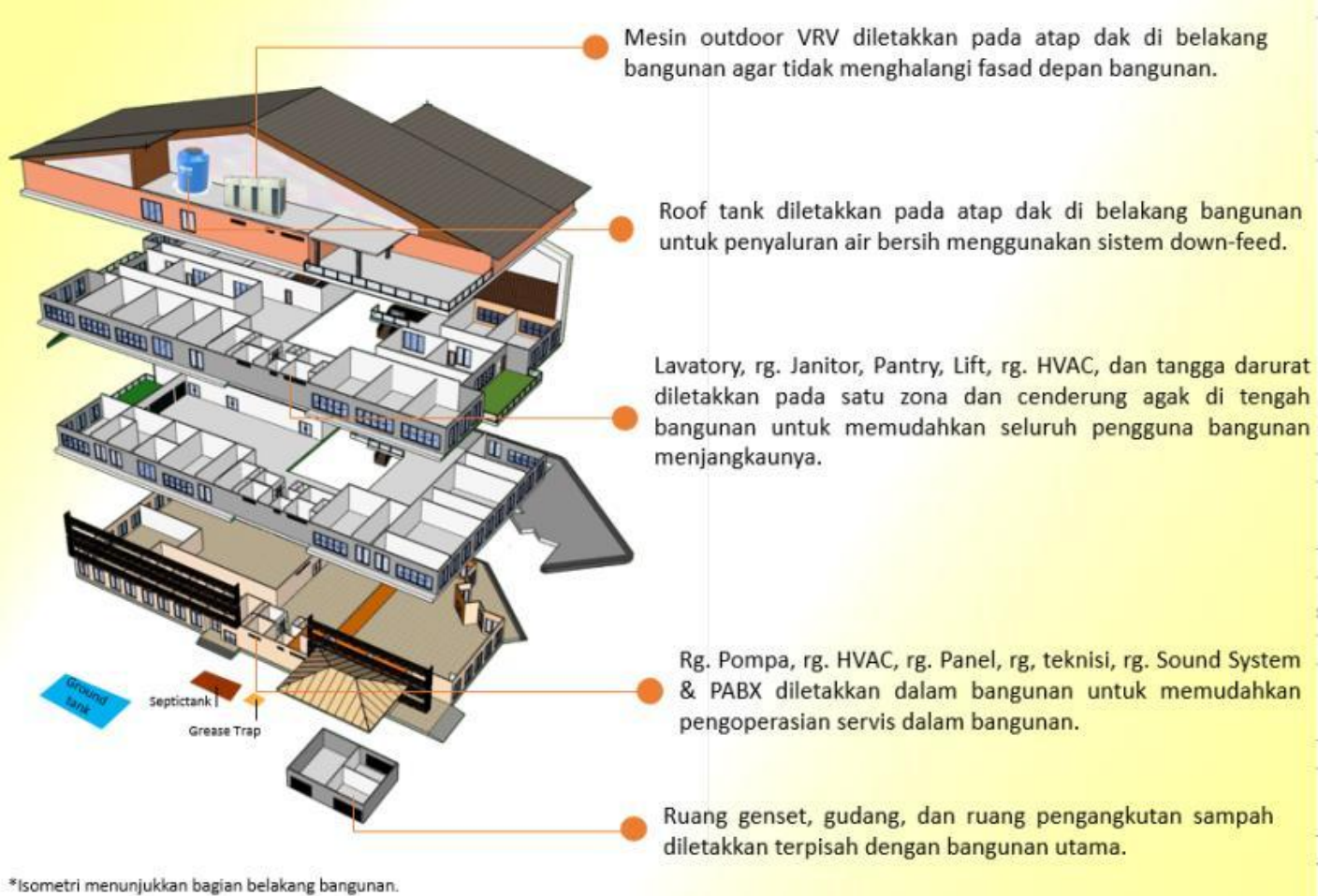

Gambar 6. Konsep Utilitas Pusat Pelatihan Bahasa Universitas Tanjungpura Sumber: Penulis, 2021 
Konsep fisika bangunan Pusat Pelatihan Bahasa Universitas Tanjungpura menerapkan sistem penghawaan, pencahayaan, dan akustika baik alami mau pun buatan. Sistem penghawaan alami diterapkan pada cross ventilation dalam bangunan, sedangkan sistem penghawaan buatan diterapkan dengan penggunaan $A C V R V$.

Sistem pencahayaan alami diterapkan dengan merancang bukaan pada bidang dinding dan juga atap (sky light), sehingga pencahayaan alami dapat menyebar merata di dalam bangunan. Sebagai pereduksian kesilauan dan mengurangi panas dari sinar matahari, maka ditambahkan secondary skin. Pencahayaan buatan berupa penerangan lampu LED tersedia pada semua ruangan untuk menunjang setiap kegiatan yang berlangsung di dalamnya.

Sistem akustika alami diterapkan pada penanaman vegetasi peredam kebisingan di sepanjang sisi jalan untuk meredam kebisingan dari kendaraan. Ruang-ruang yang memerlukan tingkat kebisingan yang rendah seperti ruang kelas, ruang aula serbaguna, dan ruang amphiteather diberikan penambahan material peredam suara pada dinding yaitu sound proof board dan acourete fiber, pada plafond yaitu panel ply wood, dan lantai menggunakan karpet, semua ini dimaksudkan untuk mereduksi suara dari luar dan suara dalam ruangan dapat tersebar rata.

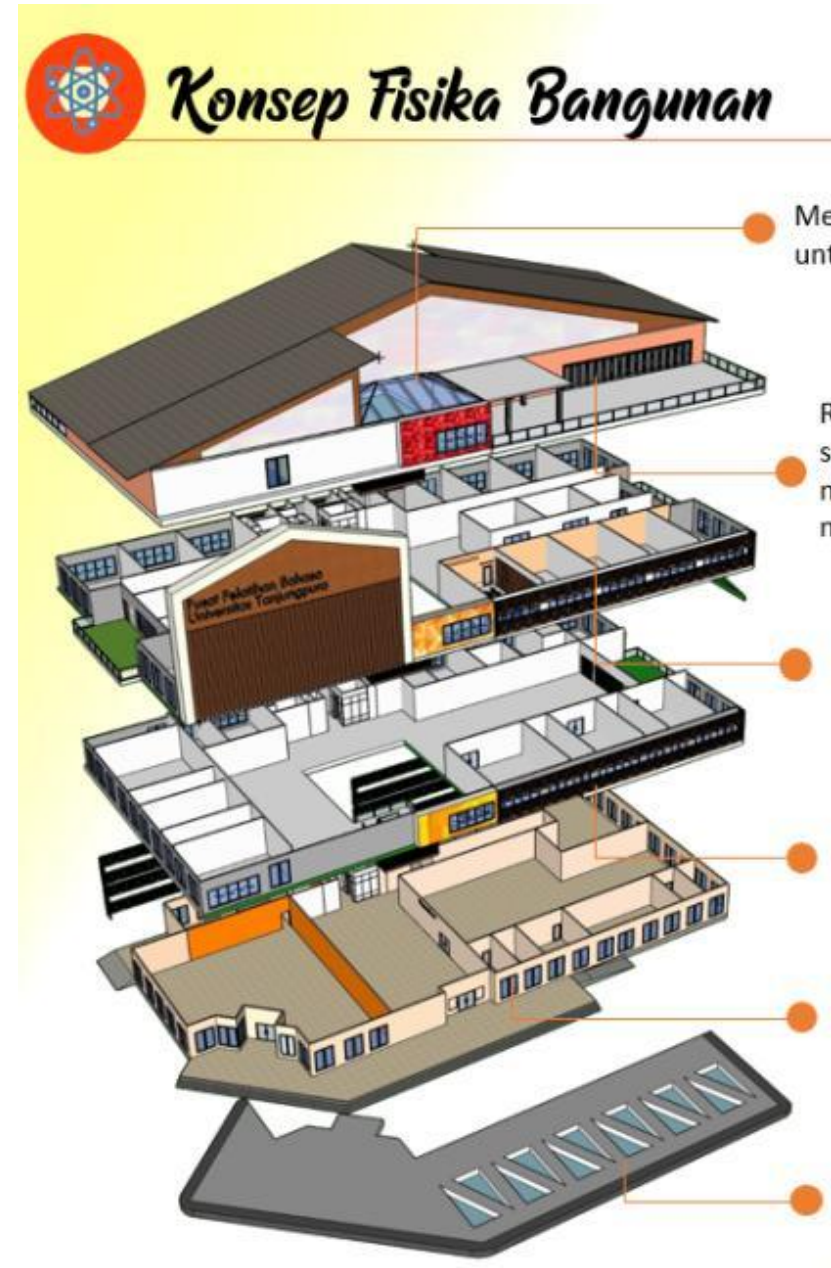

Menerapkan skylight pada bagian void di depan bangunan untuk meneruskan cahaya bola langit memasuki bangunan.

Ruang serbaguna dan rg. Amphiteather menggunakan soundproof board untuk mereduksi suara dari luar. Lantai menggunakan karpet sebagai elemen penyerap dan dinding menggunakan Acourete fiber sebagai elemen pemantul.

Ruang kelas menggunakan soundproof board untuk mereduksi suara dari luar. Ruang kelas menggunakan moveable wall sehingga besaran ruang dapat disesuaikan dengan kebutuhan ruang.

Penggunaan double glass yang mereduksi suara serta penambahan secondary skin untuk mereduksi kesilauan serta cahaya matahari yang membawa fasad.

Ruang-ruang menggunakan jendela yang bisa dibuka dan ditutup sehingga menjadi cross ventilation bagi penghawaan di dalam bangunan.

Kanopi drop off menyesuaikan bentuk miring pada lantai 1 dengan bentukan kaca berbentuk segitiga untuk memanfaatkan pencahayaan alami.

Gambar 7. Konsep Fisika Bangunan Pusat Pelatihan Bahasa Universitas Tanjungpura Sumber: Penulis, 2021

\section{Hasil Perancangan}

Hasil dari keseluruhan analisis dan konsep menghasilkan gambar pra-rancangan Pusat Pelatihan Bahasa Universitas Tanjungpura yang mencakup bangunan utama beserta kawasannya yang terdiri dari parkir umum, area parkir pengelola, serta area taman dan plaza. Pusat Pelatihan 
Bahasa Universitas Tanjungpura terdiri dari satu massa dengan empat lantai. Akses ke tapak bangunan terdiri dari empat jalur yang berbeda, untuk jalur masuk dan keluar pengunjung terletak di tenggara dan barat daya. Untuk jalur masuk dan keluar pengelola dan servasi berada di bagian utara dan barat laut. Area publik mempunyai parkiran umum yaitu sebanyak 150 buah parkiran motor dan 60 buah parkiran mobil. Zona parkir pengelola dan servis terdiri dari 40 buah parkiran motor dan 6 buah parkiran mobil. Jalur pedestrian terletak di tepi Jalan Daya Nasional menuju ke taman dan plaza di dalam tapak.
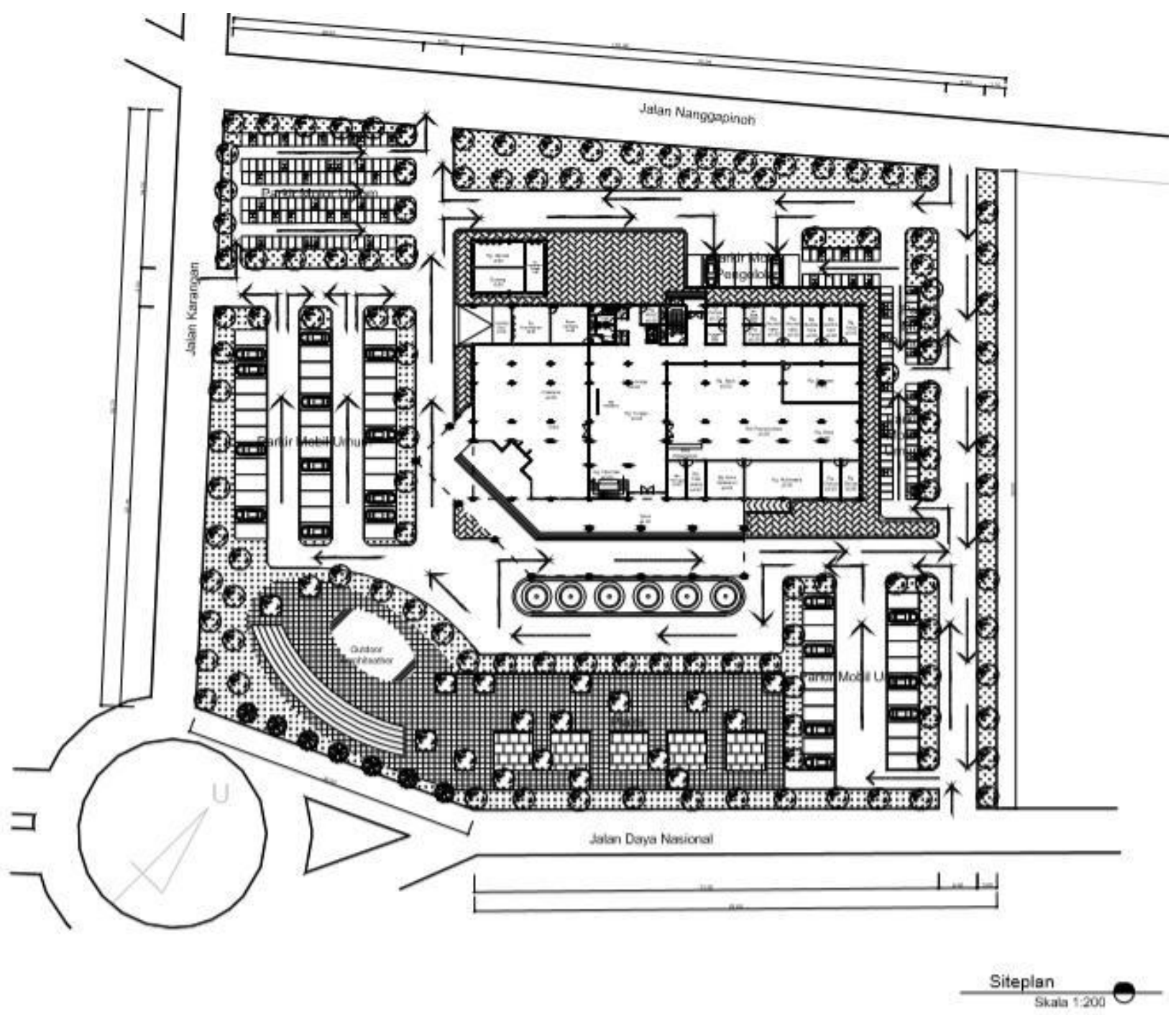

Gambar 8. Site Plan Pusat Pelatihan Bahasa Universitas Tanjungpura Sumber: Penulis, 2021

Pusat Pelatihan Bahasa Universitas Tanjungpura terdiri dari satu massa yang memiliki empat lantai. Lantai satu terdiri fungsi pendidikan (lobby, ruang informasi, ruang tunggu, area lounge, perpustakaan dan ruang loker, ruang baca, ruang tata usaha, ruang buku referensi, ruang diskusi, ruang multimedia), fungsi komersial (cafetaria, dapur, ruang penyimpanan), fungsi pengelola (ruang koordinator, ruang bendahara, ruang administrasi, ruang arsip, ruang pengajar), dan fungsi servis (ruang HVAC, ruang pompa, ruang teknisi \& PABX, ruang CCTV dan sound system, ruang panel, lavatory, WC difabel, ruang janitor, dan pantry). 


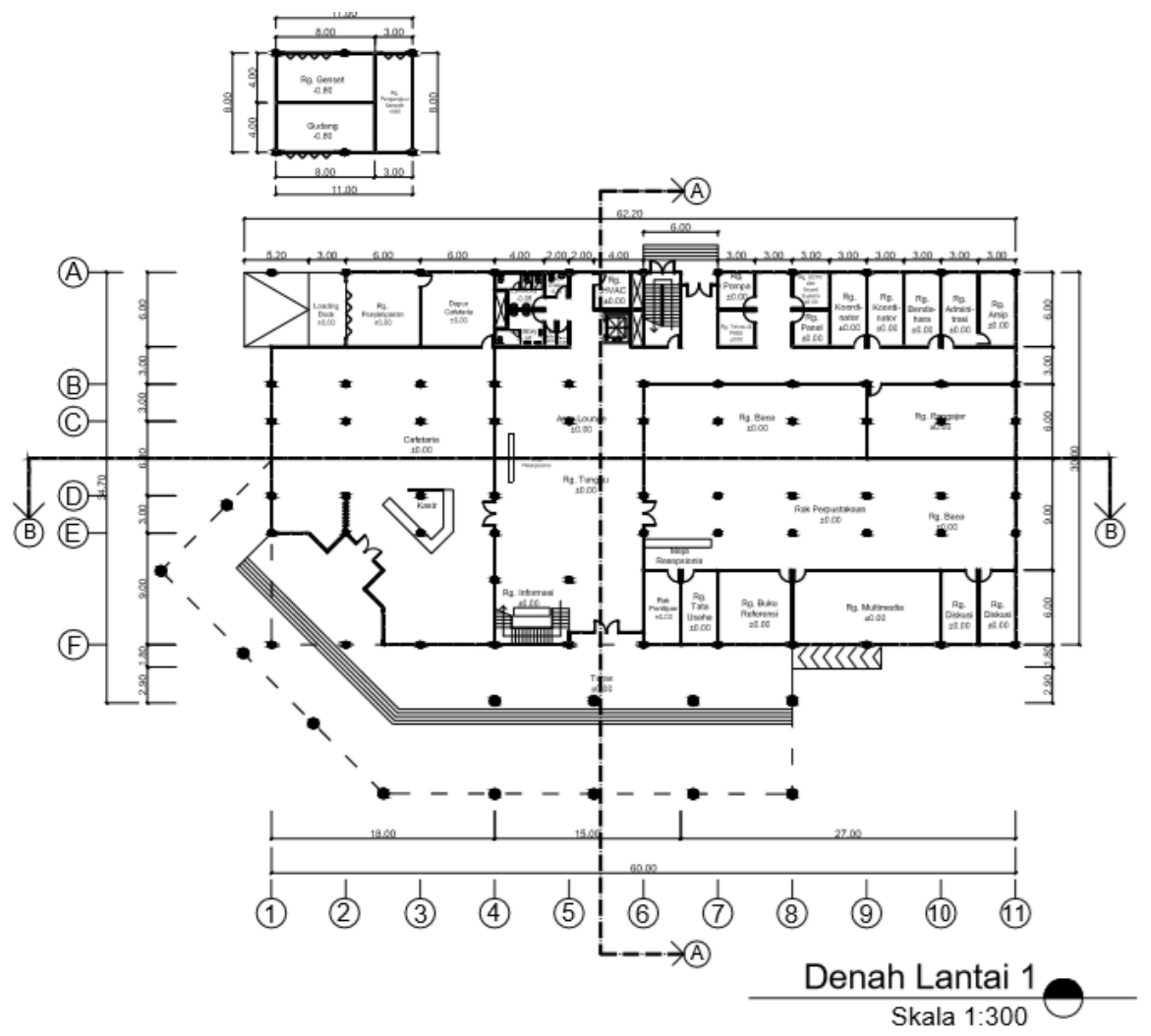

Gambar 9. Denah Lantai Satu Pusat Pelatihan Bahasa Universitas Tanjungpura Sumber: Penulis, 2021

Lantai dua terdiri fungsi pendidikan (ruang pengelola dan plaza corner), fungsi komersial (ruang pameran), fungsi pengelola (lobby pengelola, ruang tamu, ruang ketua unit, ruang ketua PTEA, ruang ketua Amcor, dan ruang rapat) dan fungsi servis (ruang HVAC, lavatory, WC difabel, ruang janitor, dan pantry).

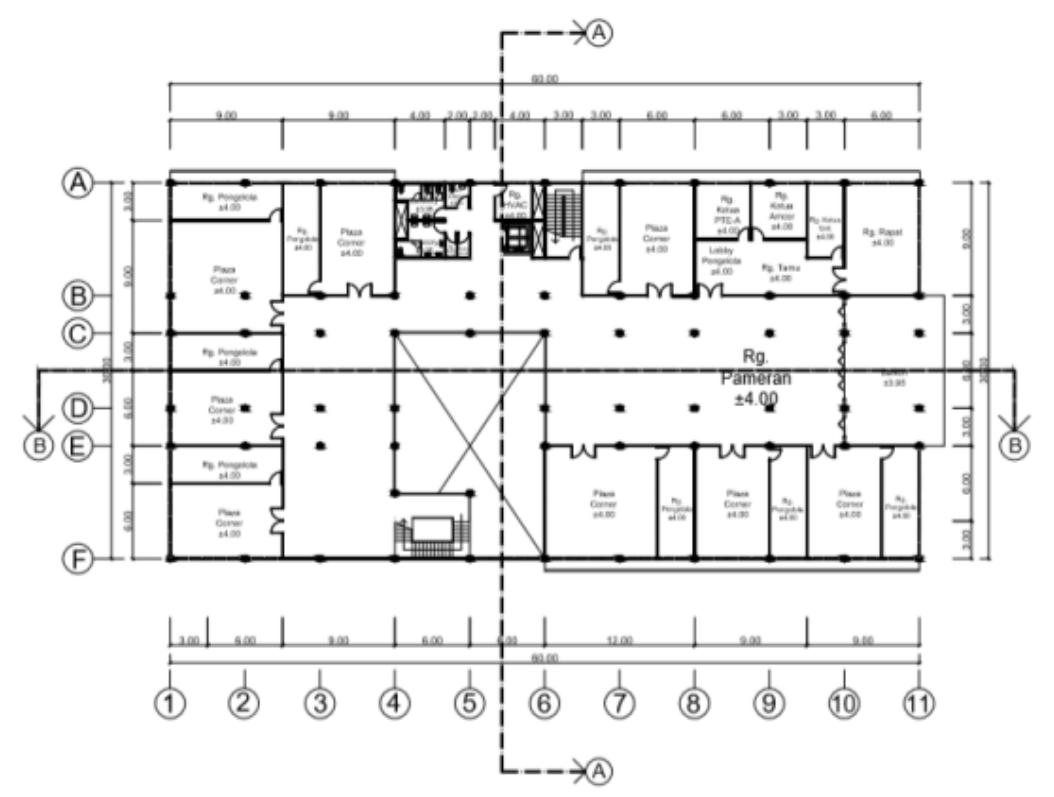

$\frac{\text { Denah Lantai } 2}{\text { Skala 1:300 }}$

Gambar 10. Denah Lantai Dua Pusat Pelatihan Bahasa Universitas Tanjungpura

Sumber: Penulis, 2021 
Lantai tiga terdiri fungsi pendidikan (ruang kelas) dan fungsi servis (ruang HVAC, lavatory, WC difabel, ruang janitor, dan pantry).

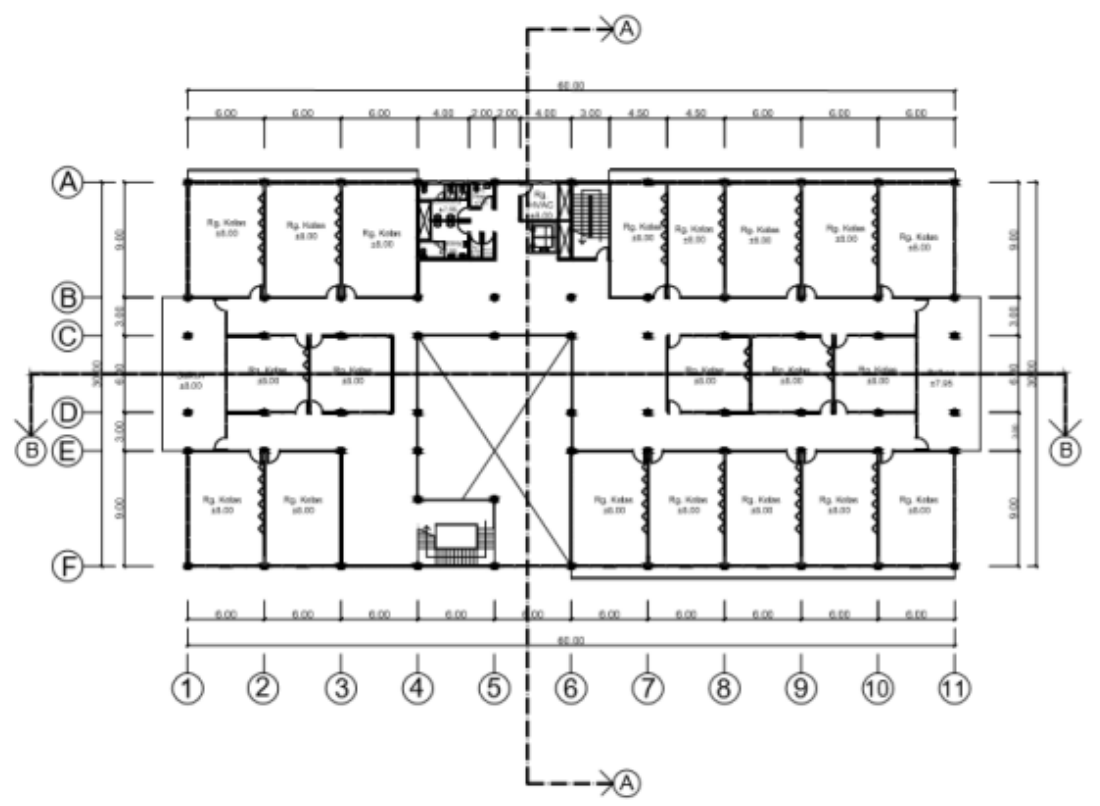

\section{Denah Lantai 3
Skala 1:300}

Gambar 11. Denah Lantai Tiga Pusat Pelatihan Bahasa Universitas Tanjungpura Sumber: Penulis, 2021

Lantai empat terdiri fungsi komersial (lobby aula serbaguna, lobby amphiteather, aula serbaguna, ruang amphiteather, cafetaria) dan fungsi servis (ruang HVAC, ruang sound system, lavatory, WC difabel, mushola, ruang wudhu, ruang janitor, dan pantry).

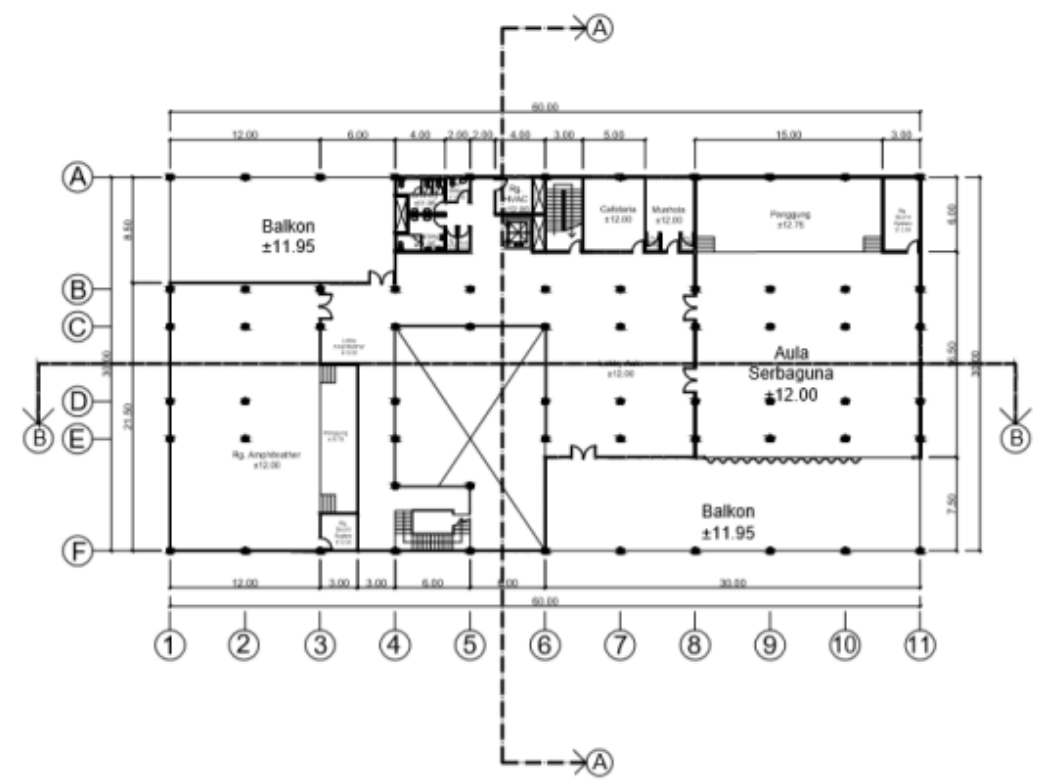

Denah Lantai 4

Skala 1:300

Gambar 12. Denah Lantai Empat Pusat Pelatihan Bahasa Universitas Tanjungpura Sumber: Penulis, 2021 
Pusat Pelatihan Bahasa Universitas Tanjungpura merupakan bangunan pendidikan dan memiliki tema fasad yaitu tema Arsitektur yang kontemporer dan Arsitektur yang menyesuaikan iklim tropis yang mempengaruhi fasad dari bentuk hingga warna. Penggunaan warna yang netral dan terlihat bersih sehingga memilih warna yang dominan yaitu warna putih, abu-abu, dan coklat.

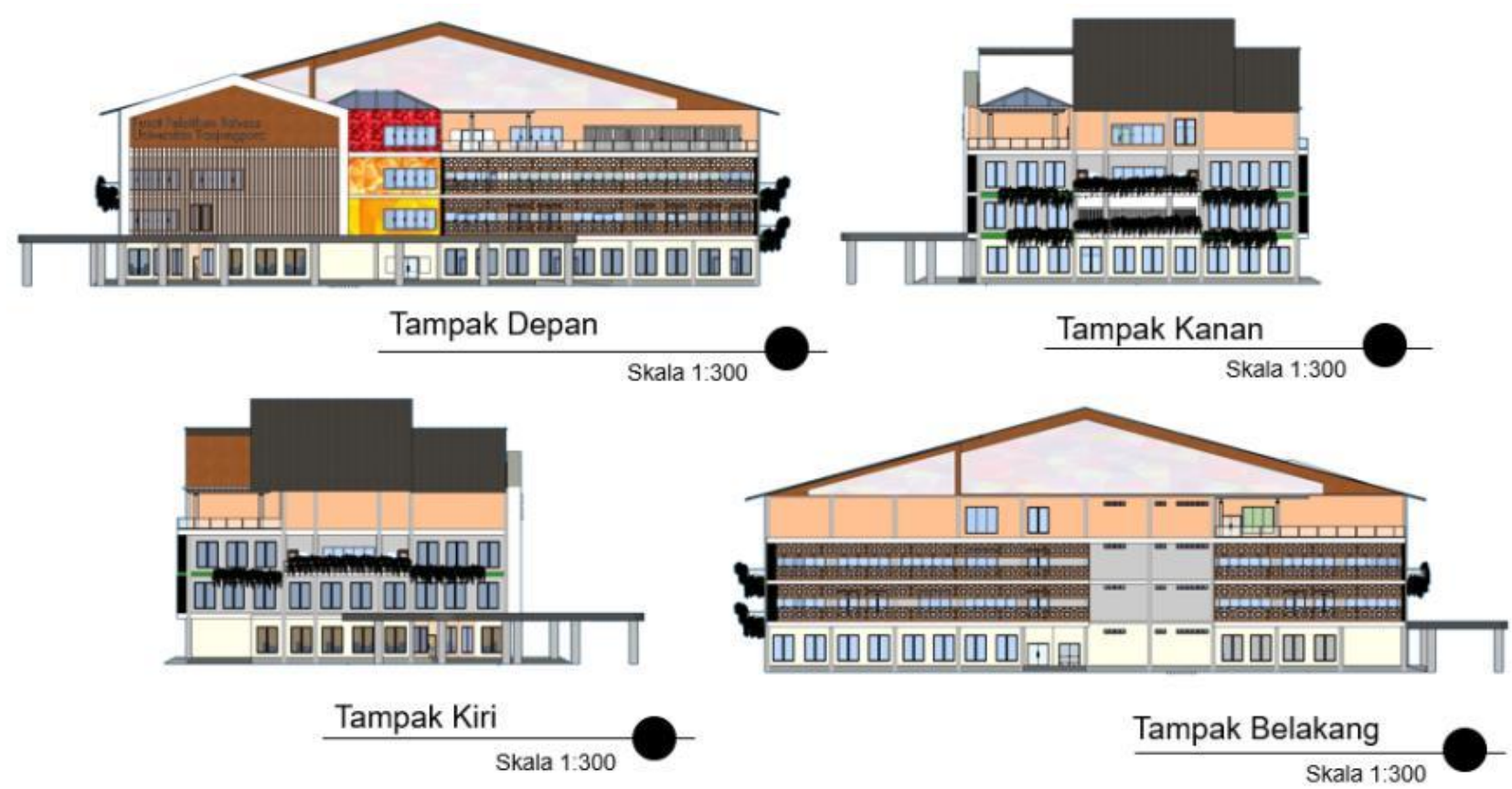

Gambar 13. Tampak Pusat Pelatihan Bahasa Universitas Tanjungpura

Sumber: Penulis, 2021

Gambar potongan bangunan Pusat Pelatihan Bahasa Universitas Tanjungpura berfungsi untuk menunjukkan struktur dan konstruksi yang diterapkan. Struktur yang diterapkan adalah struktur beton bertulang dengan konstruksi atap berupa atap pelana. Pada lantai empat terdiri dari ruang aula serbaguna dan ruang amphiteather yang bebas kolom.
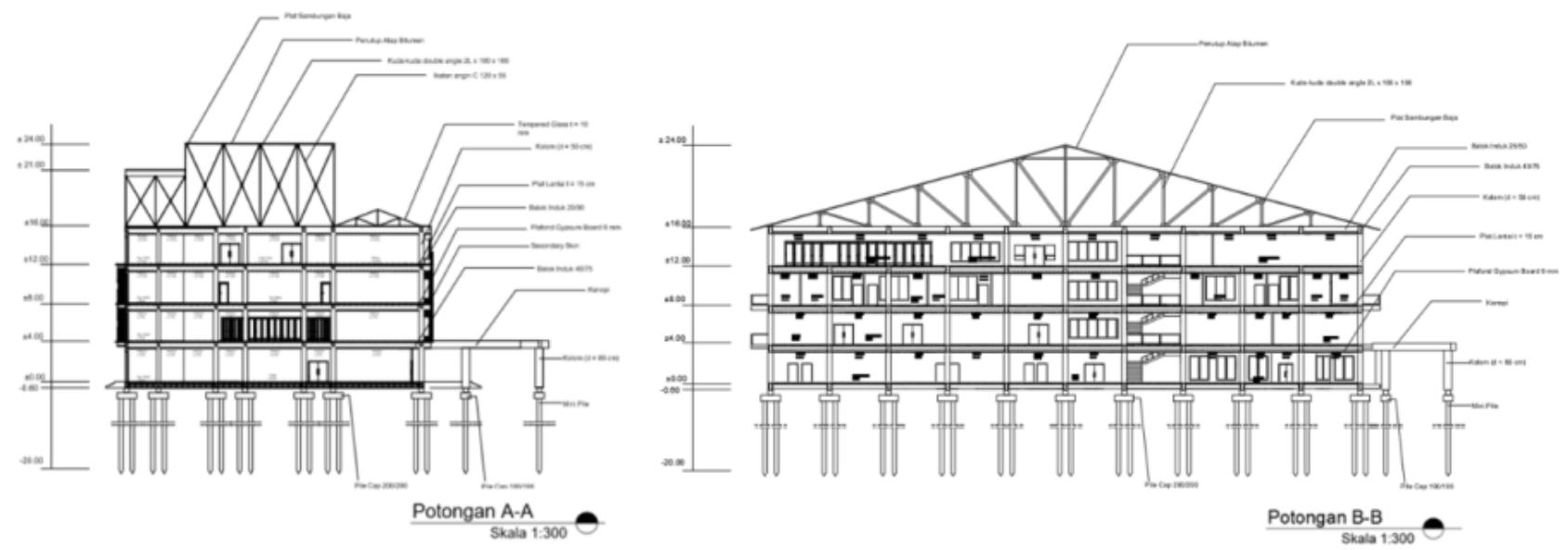

Gambar 14. Potongan Pusat Pelatihan Bahasa Universitas Tanjungpura

Sumber: Penulis, 2021

Gambar eksterior berfungsi menampilkan hubungan antara tapak dengan parkiran, taman dan plaza. Eksterior yang akan ditampilkan berjumlah dua visual bangunan, yaitu sisi depan entrance utama bangunan dan perletakan taman plaza sebagai ruang publik. Tampak depan bangunan menggunakan unsur segitiga yang merupakan bentuk ciri khas Universitas Tanjungpura. Secondary 
skin yang digunakan menggunakan motif pola khas yang dipakai pada bangunan Universitas Tanjungpura eksisting. Warna dasar yang digunakan adalah putih, abu-abu, dan coklat yang menimbulkan kesan hangat secara psikologis. Pada tampak depan digunakan tiga warna yang kontras yaitu merah, jingga, dan kuning yang diambil dari filosofis bahasa yang beraneka ragam dan bervariasi namun indah jika disatukan.
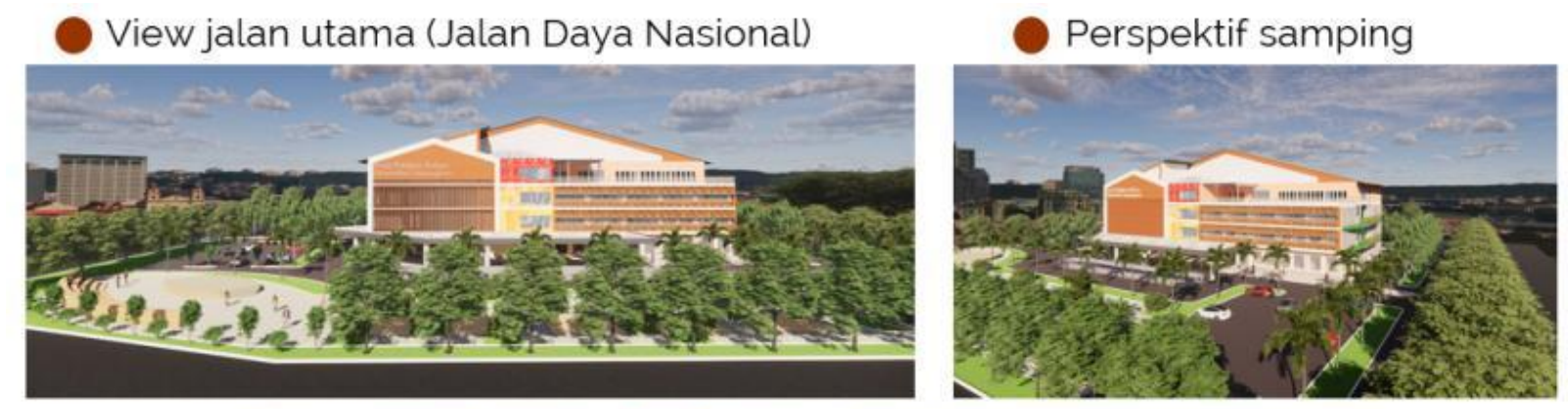

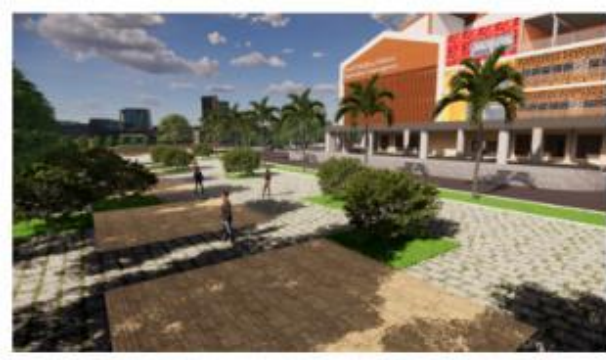

Taman dan Plaza

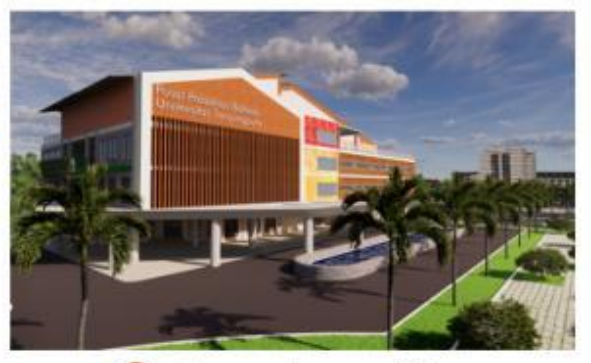

Area drop off

Gambar 15. Suasana Eksterior Pusat Pelatihan Bahasa Universitas Tanjungpura

Sumber: Penulis, 2021

Suasana interior berfungsi untuk menunjukkan material, warna dan perabot yang digunakan. Pada lantai pertama tersedia lobby dan area lounge yang menjadi ruang pertama yang dikunjungi pengunjung saat masuk ke bangunan Pusat Pelatihan Bahasa. Pada lantai pertama juga terdapat perpustakaan, ruang multimedia, dan cafetaria. Warna untuk ruang bersifat pendidikan menggunakan warna dasar putih dan krim yang menimbulkan rasa tenang dan ringan secara psikologis. Sedangkan pada ruang cafetaria menggunakan warna jingga yang dapat menggunggah selera makan. Ruang kelas terletak pada lantai tiga dan menggunakan dasar warna putih, krim, dan coklat. Selain itu ditambahkan beberapa warna kontras seperti warna merah, jingga, kuning, hijau, dan biru untuk meningkatkan antusiasme pelajar dalam belajar.
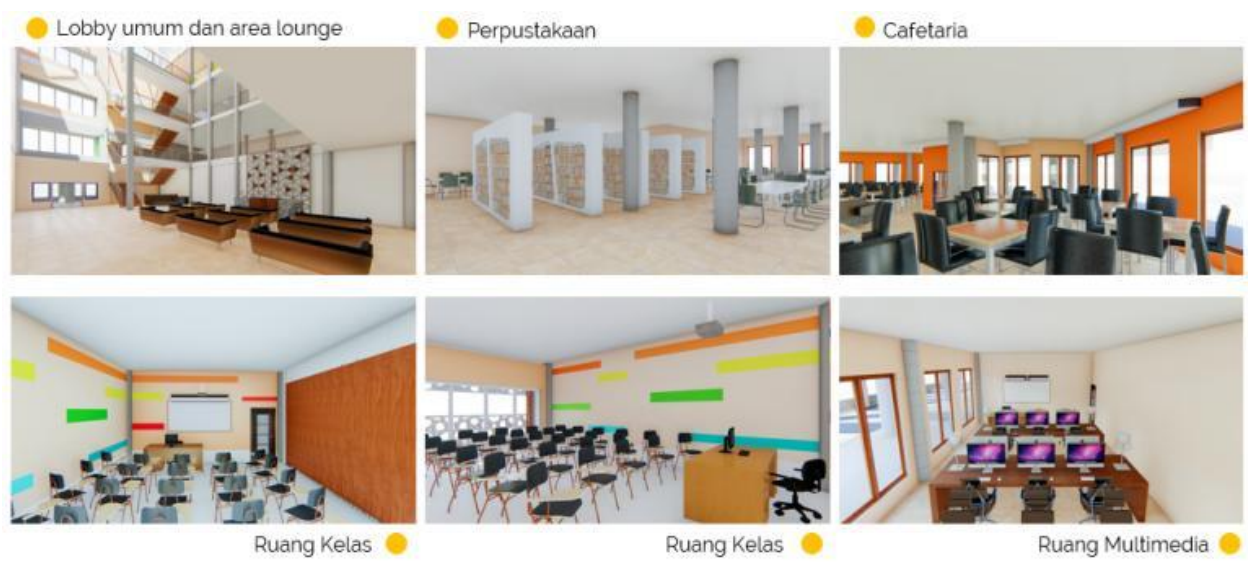

Gambar 16. Suasana Interior Pusat Pelatihan Bahasa Universitas Tanjungpura

Sumber: Penulis, 2021 


\section{Kesimpulan}

Pusat Pelatihan Bahasa Universitas Tanjungpura menjadi wadah untuk mendukung pembelajaran bahasa asing serta terdapat area bersifat komersial. Pusat Pelatihan Bahasa Universitas Tanjungpura merancang tata ruang luar dan tata ruang dalam yang bersifat publik guna menarik masyarakat mengunjungi Pusat Pelatihan Bahasa dan belajar bahasa asing. Pusat Pelatihan Bahasa ini memberikan suasana menarik yang diwujudkan pada fasilitas bersama fungsi pendidikan, komersial, dan rekreasi. Sehingga Pusat Pelatihan Bahasa ini dapat menciptakan lingkungan belajar yang baik bagi pembelajaran bahasa asing di Universitas Tanjungpura.

\section{Ucapan Terima Kasih}

Saya mengucap syukur kepada Tuhan Yang Maha Esa, kepada kedua orang tua, kepada para dosen pembimbing Tugas Akhir yaitu bapak Tri Wibowo Caesariadi ST., MT. selaku pembimbing utama dan bapak Hamdil Khaliesh S.T., M.T. selaku pembimbing pendamping yang dengan sabar memberikan bimbingan, kritik dan saran untuk penulis. Kepada teman-teman dan sahabat yang telah memberikan doa dan dukungan dalam pengerjaan Tugas Akhir ini, penulis mengucapkan terima kasih sebesar-besarnya.

\section{Daftar Acuan}

Hamalik, O. (2007). Manajemen Pelatihan Ketenagakerjaan Pendekatan Terpadu. Jakarta: Bumi Aksara

Kementerian Keuangan Republik Indonesia. (2017). Keputusan Menteri Keuangan Republik Indonesia no 830/KMK.05/2017. Jakarta: Kementerian Keuangan Republik Indonesia

Noe, R. A. (2002). Employee Training and Development. Second Edition. New York:McGraw-Hill Companies

Pemerintah Kota Pontianak. (2017). Peraturan Daerah Kota Pontianak Nomor 2 Tahun 2013 Tentang Rencana Tata Ruang Wilayah Kota Pontianak Tahun 2013-2033. Retrieved from Jaringan Dokumentasi dan Informasi Hukum Pemerintah Kota Pontianak: https://jdih.pontianakkota.go.id/peraturan/peraturan-daerah-kota-pontianak-nomor-2tahun-2013-tentang-rencana-tata-ruang-wilayah

Pemerintah Republik Indonesia. (2012). Peraturan Pemerintah Republik Indonesia Nomor 74 Tahun 2012 Tentang Perubahan Atas Peraturan Pemerintah Nomor 23 Tahun 2005 Tentang Pengelolaan Keuangan Badan Layanan Umum. Jakarta: Pemerintah Republik Indonesia

Rivai, V., \& Sagala, E. J. (2011). Manajemen Sumber Daya Manusia untuk Perusahaan. Jakarta: Rajawali Pers

Snyder, C. J., \& Catanese, A. J., (1989). Perencanaan Kota. Jakarta: Erlangga

Sugiyono. (2002). Manajemen Diklat. Bandung: Alfabeta

Suherman, A. (2011). Pembelajaran Bahasa Asing. Bandung: Universitas Pendidikan Indonesia

UPT Teknologi Informasi dan Komunikasi. (n.d.). Universitas Tanjungpura. Retrieved from https://www.untan.ac.id/menuju-blu-untan-bahas-susunan-standar-pelayanan-publik/ 